\title{
European Perspectives on the Adoption of Nonchemical Weed Management in Reduced-Tillage Systems for Arable Crops
}

\author{
Bo Melander, Nicolas Munier-Jolain, Raphäl Charles, Judith Wirth, Jürgen Schwarz, Rommie van der Weide, \\ Ludovic Bonin, Peter K. Jensen, and Per Kudsk*
}

\begin{abstract}
Noninversion tillage with tine- or disc-based cultivations prior to crop establishment is the most common way of reducing tillage for arable cropping systems with small grain cereals, oilseed rape, and maize in Europe. However, new regulations on pesticide use might hinder further expansion of reduced-tillage systems. European agriculture is asked to become less dependent on pesticides and promote crop protection programs based on integrated pest management (IPM) principles. Conventional noninversion tillage systems rely entirely on the availability of glyphosate products, and herbicide consumption is mostly higher compared to plow-based cropping systems. Annual grass weeds and catchweed bedstraw often constitute the principal weed problems in noninversion tillage systems, and crop rotations concurrently have very high proportions of winter cereals. There is a need to redesign cropping systems to allow for more diversification of the crop rotations to combat these weed problems with less herbicide input. Cover crops, stubble management strategies, and tactics that strengthen crop growth relative to weed growth are also seen as important components in future IPM systems, but their impact in noninversion tillage systems needs validation. Direct mechanical weed control methods based on rotating weeding devices such as rotary hoes could become useful in reduced-tillage systems where more crop residues and less workable soils are more prevalent, but further development is needed for effective application. Owing to the frequent use of glyphosate in reduced-tillage systems, perennial weeds are not particularly problematic. However, results from organic cropping systems clearly reveal that desisting from glyphosate use inevitably leads to more problems with perennials, which need to be addressed in future research.
\end{abstract}

Nomenclature: Catchweed bedstraw, Galium aparine L.; barley, Hordeum vulgare L.; maize, Zea mays L.; oilseed rape, Brassica napus L.; wheat, Triticum aestivum L.

Key words: Cultural control, grass weeds, nonchemical control, noninversion tillage, preventive control.

El cultivar sin inversión del suelo usando discos o picos, antes del establecimiento del cultivo, es la forma más común de reducir la labranza en sistemas de cultivos arables que incluyen cereales, colza y maíz en Europa. Sin embargo, nuevas regulaciones sobre el uso de plaguicidas podrían afectar la expansión de los sistemas de labranza reducida. La agricultura europea ha sido llamada a ser menos dependiente de los plaguicidas y a promover programas de protección de cultivos basados en los principios de manejo integrado de plagas (IPM). Los sistemas de labranza convencional sin inversión del suelo dependen totalmente de la disponibilidad de productos con glyphosate, y el consumo de herbicidas es mayoritariamente superior al compararse con sistemas de cultivo basados en el uso de arado. Malezas como zacates anuales y Galium aparine frecuentemente constituyen el principal problema de malezas en sistemas de labranza sin inversión del suelo y rotaciones de cultivos que además tienen proporciones muy altas de cereales de invierno. Existe la necesidad de rediseñar los sistemas de cultivos para permitir una mayor diversificación de las rotaciones de cultivos para así combatir estos problemas de malezas con un uso menor de herbicidas. Cultivos de cobertura, sistemas de manejo con residuos de cultivos, y tácticas que refuercen el crecimiento del cultivo en relación con el crecimiento de las malezas son también vistos como componentes importantes en los sistema IPM futuros, pero su impacto en los sistemas de labranza sin inversión del suelo necesita validación. Los métodos de control mecánico de malezas directo basados en implementos rotativos de deshierba, tales como azadones rotativos, han sido útiles en sistemas de labranza reducida donde la presencia de más residuos de cultivos y suelos menos trabajables son prevalentes, pero un mayor desarrollo de estos métodos es necesario para su aplicación efectiva. Debido al uso frecuente de glyphosate en sistemas de labranza reducida, las malezas perennes no son particularmente problemáticas. Sin embargo, resultados en sistemas de producción orgánicos han revelado claramente que el desistir del uso de glyphosate lleva inevitablemente a más problemas con malezas perennes, lo que necesita ser incluido en investigaciones futuras.

\footnotetext{
DOI: 10.1614/WT-D-12-00066.1

* First, eighth, and ninth authors: Associate Professor, Senior Scientist, and Head of Section, Aarhus University, Department of Agroecology, DK-4200 Slagelse, Denmark; second author: Weed Scientist, INRA, UMR1347 Agroécologie, BP 86510, F-21000 Dijon, France; third and fourth authors: both Head of Research Units, Agroscope Changins-Wädenswil ACW, Switzerland; fifth author: Weed Scientist, Julius Kühn-Institute, Federal Research Centre for Cultivated Plants, Institute for Strategies and Technology Assessment, Stahnsdorfer Damm 81, 14532 Kleinmachnow, Germany; sixth author: Senior Scientist, Wageningen University, Department of Applied Plant Research, Edelhertweg 1, 8219PH Lelystad, the Netherlands; seventh author: Weed Specialist, ARVALIS, Institut du végétal, Station Expérimentale, 91720 Boigneville, France. Corresponding author’s E-mail: bo.melander@agrsci.dk
}

Reduced-tillage systems for the major agronomic crops in central and northern Europe cover various practices ranging from no-tillage (direct drilling) to occasionally inverting the soil. The major crops predominantly comprise small grain cereals, winter oilseed rape, and maize. For the purpose of this review, the term "reduced tillage" (RT) will be used to refer to practices which do not involve conventional tillage (CT) with a moldboard plow. Such RT practices range from notillage (NT) to full-width noninversion tillage (NIT). NIT systems based on shallow tine or disc cultivation are the most 
common and now cover approximately 10, 10, 30, and 30\% of the cropped area in Denmark, France, Germany, and Switzerland, respectively (Berner Fachhochschule $[\mathrm{CH}]-$ Verfahrenstechnik im Pflanzenbau, B. Streit, personal communication; Labreuche et al. 2008; Pallutt 2011; The Danish Extension Service, personal communication). Cultivation depth and number of passes of NIT systems vary considerably depending on soil type, climate, and experiences, and to some extent tradition. NT has very little uptake in most countries, accounting for only a small percentage of the total arable area (Soane et al. 2012). RT is mainly practiced by arable growers and pig producers with a high demand for forage grain. Dairy producers, however, show little interest in changing from CT.

Time saving is the major motivation for reducing the input of tillage in low-land areas, whereas the prevention of soil erosion seems to be the driving factor for mountainous areas. For example, in Switzerland, one quarter of the cultivated land is affected by water erosion, and large amounts of eroded soil are often related to slope depressions, frequently resulting in off-site impacts (Ledermann et al. 2010). The structural changes of farm enterprises into larger acreages managed by the same work force have accentuated the need to look for time savings to maintain timeliness in field operations. In addition, savings in expenditures for machinery and fuel are important motivations for adopting RT to further improve revenues (Davies and Finney 2002; Jacobsen and Ørum 2009; Morris et al. 2010). This has become even more topical with rising fuel and commodity prices in recent years. However, research, extension services and growers are also aware of other benefits that RT can provide. Notably, enhancement of soil quality (improved soil structure, increased activity of soilborne microbes and invertebrates, increased soil organic matter content), reduction of nutrient losses through leaching, and reduction of greenhouse gas releases are often emphasized as beneficial effects (Holland 2004; Morris et al. 2010).

Perhaps the greatest constraint to adoption of RT systems in Europe is weed control. When tillage frequency and depth are reduced, fewer weeds are uprooted, buried or injured, resulting in either increased reliance on other weed management practices (e.g., herbicides) or yield losses. In addition, the efficacy of many herbicides has been shown to be reduced under RT due to (1) increased adsorption in surface layers of untilled soil with higher organic matter (P. Kudsk, unpublished data; Pedersen et al.1995); (2) physical interception and adsorption of soil surface residues (Erbach and Lovely 1975); and (3) development of herbicide resistance. In Europe, herbicide resistance, particularly in grass weeds, including blackgrass (Alopecurus myosuroides Huds.), is considered a major threat to adoption of RT (Morris et al. 2010). For example, models of herbicide resistance development suggest that RT increases the risk of target-site resistance to ACCase inhibitors of blackgrass (Cavan et al. 2000) and glyphosate in rigid ryegrass (Lolium rigidum Gaudin) (Neve et al. 2003).

Due to the increased difficulty of controlling weeds in RT systems, growers adopting RT have often relied on greater use of herbicides, especially glyphosate and other herbicides, to control annual grasses (Chauvel et al. 2011; Clarke et al. 2000; Jacobsen and Ørum 2009; Melander et al. 2010b; Vullioud and Mercier 2004). Increased use of glyphosate was reported with the development of cover crops and simplification in soil tillage, rising from $0.034 \mathrm{~kg} \mathrm{ha}^{-1}$ to $0.141 \mathrm{~kg}$ $\mathrm{ha}^{-1}$ arable land, according to a network of pilot farms monitored over $12 \mathrm{yr}$ in Switzerland (Dugon et al. 2010). The most comprehensive records are probably those of Freier et al. (2010), who recorded higher herbicide use on German farms practicing NIT compared to CT during the 2007 to 2010 growing seasons. Higher herbicide use ranged from 5 to $18 \%$ in winter wheat, 27 to $46 \%$ in winter barley, and 36\% in oil seed rape. Similar increases in herbicide use in RT systems as compared to CT were observed in large agricultural surveys conducted in the 2000s in France (Chauvel et al. 2011). The German and French results varied considerably between fields due in part to crop rotation history. Results from a 34-yr experiment with RT in Switzerland at Changins (1970 to 2003) showed that costs for weed control were higher for all RT treatments: about $20 \%$ for NT and 5 to $8 \%$ for NIT, respectively (Vullioud and Mercier 2004). The higher costs could be explained by a larger increase of the weed seed bank with RT (Vullioud et al. 2006).

New pesticide regulations in Europe create strong incentives for growers to limit herbicide applications, and partly account for reductions in NIT acreage. In Denmark, the area with NIT rose noticeably in the late 1990s and the beginning of the 2000s but has stagnated since then. Cropping-related issues, such as crop failures, unsuitable soil types for minimizing tillage, and limitation in practitioners' skills, are among the causes for this stagnation. However, the primary cause seems to come from pesticide legislation. Several pesticide action plans have been launched since the late 1980s in Denmark, all asking for a reduction in herbicide use (Jørgensen and Kudsk 2006). Similar action plans with analogous goals have also been introduced in Germany (Anonymous 2012a), France (Anonymous 2012b), and the Netherlands. On top of this, the European Union (EU) has recently passed a directive that imposes on each member state the initiation of measures that will push crop protection toward integrated pest management solutions (EU Directive/ 128/EC 2009; Hillocks 2012). In brief, these measures will mandate reductions in pesticide use through promotion of nonchemical methods, as well as reductions of pesticide rates and frequency of applications. Restrictions on stubble cultivation and an obligation for more catch crops growing in the autumn to minimize nutrient leaching are other legislative demands affecting weed control in RT systems. Such impositions have been introduced in France and Denmark recently.

The EU and national regulations on herbicide use could endanger the future of RT in Europe unless weed control techniques are developed and modified to meet the new situation. In this paper, we review the perspectives of adopting nonchemical weed management in RT systems for the major agronomic crops in central and northern Europe. First we summarize the major weed problems associated with these cropping systems. Then the review encompasses preventive, cultural, and direct weed control methods, which we believe can play an important role in future RT systems, with less reliance on herbicide inputs. 
Table 1. Weed species reported to be associated with the major agronomic crops grown in reduced-tillage systems in central and northern Europe.

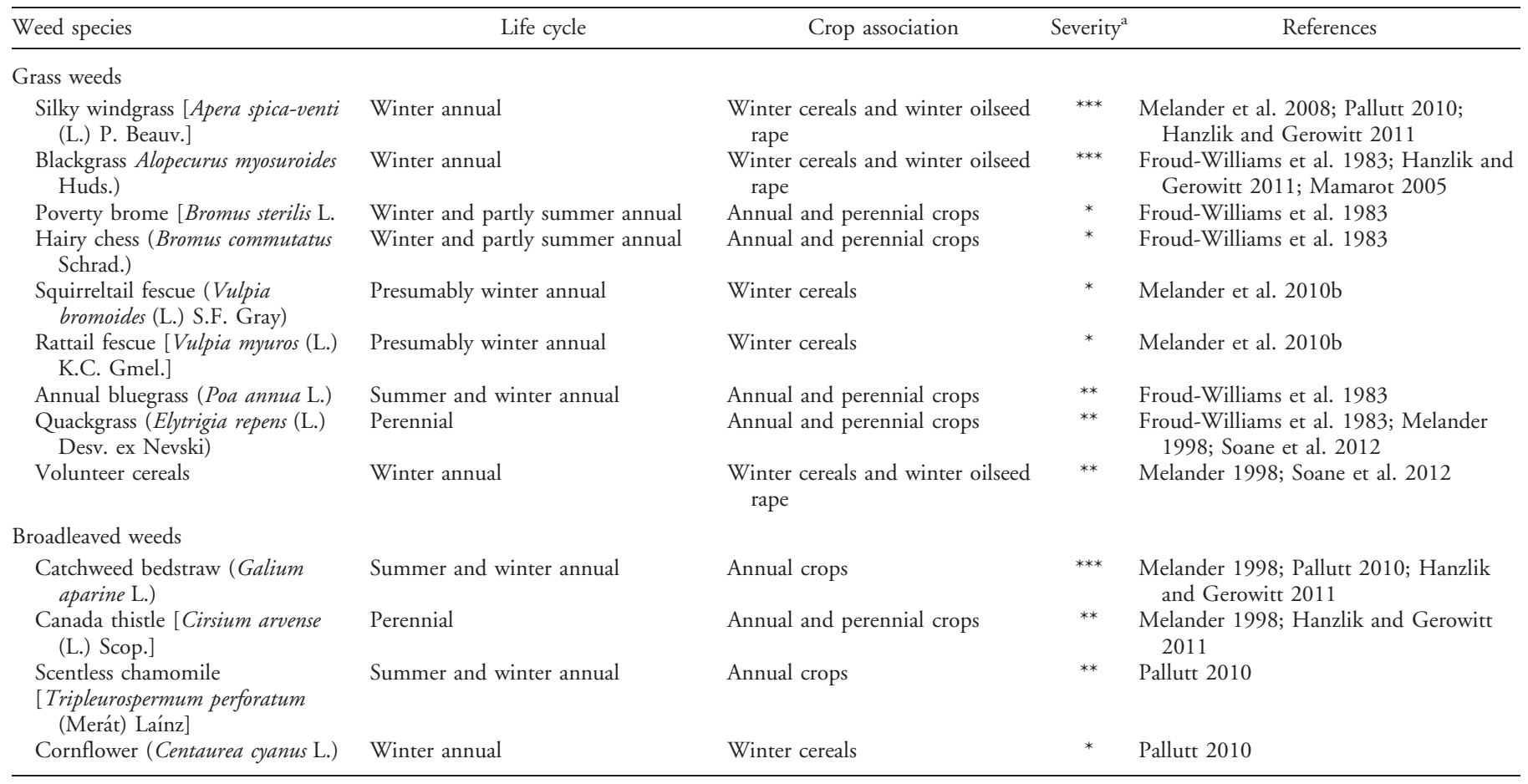

${ }^{a}$ Severity indicated with ${ }^{* * *}$, and ${ }^{* * *}$, respectively, where ${ }^{* * *}$ denotes highest severity. Judgements are made according to prevalence and impact on crop growth.

\section{Problematic Weed Species}

The European literature is quite consistent about annual grass weeds being the major weed problem with RT (Table 1). Annual grasses typically have short-lived seeds with little innate dormancy and predominantly constitute a weed problem in winter cereals. Winter cereals are frequently grown in RT systems, which can result in a weed flora having few species occurring in high numbers. The incidence depends on the proportion of winter cereals grown in the crop rotation (Melander 1994). Weed seeds exhibiting marked dormancy characteristics and greater longevity are better adapted to CT because seed germination and mortality decrease with increasing soil depth; traits that are mostly found among dicotyledonous species such as common chickweed [Stellaria media (L.) Vill.], common lambsquarters (Chenopodium album L.), and corn poppy (Papaver rhoeas L.) (Melander 1994; Morris et al. 2010).

Among the species mentioned in Table 1, blackgrass, silky windgrass [Apera-spica-venti (L.) P. Beauv.] and catchweed bedstraw are particularly problematic in NIT systems, especially if crop sequences concurrently favor their proliferation (Clarke et al. 2000; Melander et al. 2008; Pallutt 2010; Wilson and Wright 1991; Zwerger et al. 1990). Crop yields can be strongly affected, resulting in severe yield losses (Melander 1995; Melander et al. 2008).

Perennial weed species, especially quackgrass [Elytrigia repens (L.) Desv. ex Nevski], were formerly reported to cause severe problems in long-term experiments with NIT (Rasmussen 1984). This was primarily observed before the introduction of glyphosate or before standards for effective application in practice became commonly known. Today it seems that the frequent use of glyphosate in conjunction with other effective herbicides against perennials (e.g., MCPA against Canada thistle [Cirsium arvense (L.) Scop.] suffices to keep perennials at manageable levels in NIT systems (Melander, personal observations; Orson 2006; Vullioud et al. 2006). However, studies from organic experiments, representing a zero herbicide scenario, have clearly revealed that NIT can lead to unacceptable infestations of Canada thistle, and CT is seen as a necessary prerequisite for effective management (Gruber and Claupein 2009; Peigné et al. 2007; Pekrun and Claupein 2004). Postharvest tillage operations affect perennials through mechanical disintegration, uprooting, desiccation, exhaustion, and/or burial of belowground vegetative propagules, the exact mechanism depending on the tool configuration, the number of passes, and whether different implements are combined within the same strategy (Melander 1994).

Wind-disseminated weed species, notably sowthistle (Sonchus spp.), willowherb (Epilobium spp.), and common groundsel (Senecio vulgaris L.), and perennials such as docks (Rumex spp.) and dandelion (Taraxacum officinale F. H. Wigg.) (Froud-Williams et al. 1983) have also been observed with RT but all are of minor importance.

\section{Crop Rotation}

Current Knowledge. Crop choice and the sequence in which they are planned to follow one another have a great impact on the weed flora (Blackshaw et al. 2007). Crops have different growth cycles, ranging from annual or biennial to perennial crops of different duration and with different seasons of 
establishment. The crop rotation strongly determines the growing conditions for weeds, depending on the composition of crops; some weed species are favored whereas others might be disfavored. Weed control options also are linked to crop choice, and the spectrum of control tactics and active ingredients of herbicides usually expands with the diversification of the crop rotation (Melander et al. 2005). The strong impact of crop sequence on weed communities became particularly evident in an analysis of 257 fields selected across the U.K. by Bohan et al. (2011). They found that weed seed bank sizes of both broadleaf and grass species were more strongly affected by the crop sequence of the past $3 \mathrm{yr}$ than geographical origin or year. Extending the analyses to more than 3 yr back in time, however, did not improve the explanatory power of crop sequence. Based on this, the authors suggest that weed seeds with short longevity better explain the current state of a weed seed bank than seeds with greater longevity. The analyses have recently been extended to include data from Germany, Hungary, Denmark, and Italy, and preliminarily results again indicate that crop sequence is more important than country or origin (D. A. Bohan et al., unpublished data). Thus, the significance of modifying the crop sequence is particularly important in NIT systems because these systems tend to select for weed species having short-persisting seed banks that are more likely to be affected by diversification of the crop growth cycles (Chauvel et al. 2011).

Diversifying crop rotations usually leads to a diversified weed flora. This has been verified in several studies, but mostly where CT has been the primary method for crop establishment (e.g., Andersson and Milberg 1996, 1998; Meissle et al. 2010). The inclusion of crops repeatedly mown can further reduce weed pressure as compared to rotations entirely composed of cash crops (Schwarz and Moll 2010).

A few long-term studies have studied the interactions between RT systems and crop sequences and the need for herbicide input. In NIT systems in Dijon France, use of crop diversification, delayed sowing, and stubble cultivation resulted in a 77\% reduction in the amount of herbicide required (Chikowo et al. 2009). In particular, the addition of spring-sown crops to a winter cereal-winter oilseed rape cropping system helped disrupt weed life cycles and reduce herbicide requirements, except for blackgrass, which increased under NIT. However, in other studies with RT systems undertaken in Germany (Pallutt 2010; Zwerger et al. 1990), Denmark (Melander et al. 2008, 2010b), and Boigneville, France (L. Bonin,, unpublished data) grass weeds, such as blackgrass, silky windgrass, perennial ryegrass (Lolium perenne L.) and rattail fescue [Vulpia myuros (L.) K.C. Gmel.], could be effectively managed through crop diversification. The inclusion of spring-sown crops and perennial crops in rotations having high proportions of winter cereals reduced incidences markedly, and consequently the need for graminicides. However, crop diversification did not prevent a steady increase of catchweed bedstraw under RT, despite the use of herbicides stated to have high efficacy against that particular species (Pallutt 2010; Melander et al. 2010b).

Change of Crop Sequences. The potential for improving weed management in RT cropping systems has several practical limitations that became apparent during recent discussions within the European Commission-funded "ENDURE Network of Excellence (2007-2010)." (ENDURE is a major source of information and provides a platform for knowledge exchange regarding all aspects of integrated pest management. It builds on the experience and knowledge amassed within the network.) Crop rotation usually implies that a certain sequence of crops is grown within a certain time course for years. However, static crop sequences do not reflect common practices because there is no "typical crop rotation," but rather many different combinations of crop sequences. This became apparent when analyzing large data sets of the crops grown on fields in the U.K. and Denmark (ENDURE deliverable DR2.16. 2010). Farmers' crop choices are highly flexible and usually driven by commodity prices and the need for fodder supplies. The analysis also revealed that winter crops constitute the principal component of most crop sequences in arable cropping in northern Europe. Winter wheat, winter barley, and winter oil seed rape are the predominant winter crops, with winter wheat being most frequently grown. These crops are preferred because of a higher yield potential than the corresponding spring-sown crops and a good adaption to the climate and soils prevailing in northern Europe. The incitement of growers to change crop sequences is usually low unless economically justified. Several proposals for redesigning winter crop-based cropping systems into systems requiring less pesticide input were suggested and published in three leaflets (Ferguson and Evans 2010; Fortino et al. 2010; Melander et al. 2010a). All the proposed cropping systems considered changes of intensive winter cropping essential for redesigned cropping systems to become less dependent on pesticide usage. The ultimate goal was a strong disruption of the weed seed bank community assumed to result in a more balanced weed flora. Furthermore, all systems suggested CT as a standard tillage practice because RT was not regarded as a safeguard for less dependence on pesticides. The redesigned systems from the U.K. and Denmark were particularly aimed at combating annual grasses and catchweed bedstraw. The redesigned systems were discussed within a panel of experts representing research and extension services, but have not been subjected to more thorough analyses on their feasibility, especially the economic aspects. Similar activities resulted in comparable results for maize cropping concerning the importance of diversifying the crop rotation (Vasileiadis et al. 2011).

\section{Cover Crops}

Organic cropping systems seek to keep the soil covered with plants most of the year to optimize nutrient management (Olesen et al. 2007). Conventional cropping in Europe is moving in a similar direction, motivated through agronomic and environmental benefits and the legislative requirements mentioned earlier. The primary purpose of growing cover crops is therefore to act as a catch crop between main crops to minimize nutrient losses through leaching (Thorup-Kristensen et al. 2003).

Studies on weed management issues and cover cropping in conjunction with RT are scarce in European literature. 
Worldwide, extensive research has mostly focused on cover crops in simplified systems based on basic rotations, NT, and herbicide-resistant genetically modified crops. This information is difficult to transpose to other conditions. Still, emerging European research now focuses more specifically on the use of cover crops for weed management in RT, including other agro-systemic functions provided by cover crops. Among the few studies conducted so far, Moonen and Bàrberi (2004) investigated the interactions between tillage methods and cover cropping in a long-term experiment in Italy. They observed a $25 \%$ reduction in total weed seedbank density $7 \mathrm{yr}$ after the introduction of a rye cover crop in a CT maize system compared to the noncover-cropped system. In the NT-based maize system, however, the more suppressive cover crop was subterranean clover (Trifolium subterraneum L.), with an average $22 \%$ reduction. Differences in weed species composition and total seedbank density (approximately five-fold higher in NT than in CT) were mainly related to tillage system rather than to cover crop species. This suggests that not all cover crop/management system combinations are capable of decreasing weed pressure in a practical context. In addition, cover cropping and the need for keeping a mulch might not always be compatible with other cropping practices, such as tillage for seedbed preparation or mechanical weed control interventions (Peigné et al. 2007).

The key factor for successful weed management appears to be the fast development of a dense cover crop stand. This can be difficult to achieve in northern Europe where growing periods between crops are shorter as compared to more southern latitudes. Danish farmers attempt to meet this by broadcasting crucifer species 2 to 3 wk before harvesting cereals, aiming for an early establishment of the catch crop. For cropping systems based on mulching effects, weed control increases with increasing residue biomass, and residue biomass is more important in determining weed suppression than residue type (Teasdale 1996). In addition, timing and handling of cover crop termination are decisive for their weed-suppressive functions. In addition to chemical termination prior to crop sowing, cover crop growth can be ceased mechanically. For example, nonEuropean studies have shown that rolling down the cover crop instead of mowing resulted in slower decomposition, whereby the weed-suppressing mulching period was prolonged, in many cases reducing or eliminating the need for herbicides (Altieri et al. 2011; Lu et al. 2000). Clearly, the more biomass produced at the time of rolling or mowing, the better will be the mulching effect (Mirsky et al. 2011), but termination in late spring or early summer will limit the spectrum of cash crops that can be grown subsequently.

Despite the few results obtained under practical European conditions, we believe that cover crops can serve as a useful tool in RT systems for suppressing postharvest weed growth. However, the potential of cover crops for controlling weed populations efficiently and reliably calls for a stronger foundation in European research before making wider recommendations for RT systems. Future research needs to address aspects such as ideal attributes of plant species for weed suppression in the postharvest period, ideal timing and methods for cover crop establishment and termination, and efficient techniques to establish a subsequent crop in order to avoid excessive use of herbicides.

\section{Stubble Management}

The management of the stubble period between main crops has large implications for weed dynamics. Direct nonchemical methods such as mowing or stubble tillage can be used freely unless a cover crop has been established. Shallow postharvest tillage is an important component in NIT systems in Europe because it incorporates crop residues for decomposition and prepares the land for subsequent crops (Morris et al. 2010). Furthermore, weed growth is terminated, whereby the production of new weed seeds and belowground vegetative propagules are prevented.

Stubble tillage plays a significant role in organic crop production for the control of perennial weed species, usually requiring multiple passes for effective control (Lukashyk et al. 2008). Stubble tillage can also become an important component for weed management with the adoption of IPM in conventional crop production because the dynamics of annual weeds can be manipulated (Pekrun and Claupein 2006). In addition to the prevention of postharvest seed shedding, stubble cultivation incorporates weed seeds that have been shed prior to crop harvest or spread during harvesting. Furthermore, it stimulates the germination of older seeds in the weed seed bank. The outcome of postharvest tillage strategies on the occurrence of annuals depends on the methods applied, the composition of the weed flora, the seed production in the actual year in proportion to the seed bank, and the dormancy status of produced seeds.

Numerous reports suggest that a greater seed loss of freshly shed weed seeds can be achieved if the seeds are left on the soil surface after crop harvest rather than being incorporated into the soil (e.g., Jensen 2009; Melander et al. 2008). The responses of important annual weed species in northern Europe to stubble tillage are summarized in Table 2. Poverty brome and soft brome (Bromus hordeaceus L.) and volunteer cereals are the main exceptions to the rule that seed loss is larger when seeds are left on the soil surface as compared to incorporating the seeds. For the brome species, the larger turnover at the soil surface is dependent on other factors (Table 2). Incorporating new seeds into the soil apparently preserves the seeds for a longer time as found for the majority of species listed in Table 2. Straw cover appears to have little influence on seed survival of both monocotyledonous and dicotyledonous species whether the seeds are incorporated or exposed on the soil surface (Jensen 2009, 2010a,b).

For the management of many of the problematic annual grass weeds, the stubble is better left undisturbed because the annual seed rain constitutes the primary source for maintaining the populations. Annual grasses mostly have short-lived seeds, and tilling the stubble to diminish the seed bank might be counteracted by preservation of new seeds. The overall effect of stubble cultivation might be more neutral for dicotyledonous species having seeds with greater longevity in soil (Pekrun and Claupein 2006). Thus, in general, it seems reasonable to leave the soil undisturbed in the stubble period unless the two brome species and volunteer cereals are causing 
Table 2. Optimum stubble management strategies to reduce infestation from newly shed seeds of annual weeds in central and northern Europe.

\begin{tabular}{|c|c|c|c|c|}
\hline Weed species & $\begin{array}{l}\text { Cultivate early } \\
\text { after harvest }\end{array}$ & $\begin{array}{c}\text { Do not } \\
\text { cultivate early }\end{array}$ & Unknown/Neutral & References \\
\hline Volunteer cereals & $\checkmark$ (unless cold and wet) & & & Clarke et al. 2000 \\
\hline Wild oat (Avena fatua L.) & & $\checkmark$ & & Clarke et al. 2000 \\
\hline Blackgrass (Alopecurus myosuroides Huds.) & & $\checkmark$ & & Jensen 2009 \\
\hline Silky windgrass [Apera spica-venti (L.) P. Beauv.] & & $\checkmark$ & & Melander et al. 2008 \\
\hline Hairy chess (Bromus commutatus Schrad.) & & $\checkmark$ & & Clarke et al. 2000 \\
\hline Poverty brome [Bromus sterilis L.] & $\checkmark$ (especially if no straw) & & $\checkmark$ (if good straw cover) & Clarke et al. 2000 \\
\hline Soft brome (Bromus hordeaceus L.) & $\checkmark$ & & & Jensen 2009 \\
\hline Perennial ryegrass (Lolium perenne L.) & & $\checkmark$ & & Jensen $2010 \mathrm{~b}$ \\
\hline Roughstalk bluegrass (Poa trivialis L.) & & $\checkmark$ & & Jensen $2010 \mathrm{a}$ \\
\hline Rattail fescue [Vulpia myuros (L.) K.C. Gmel.] & & $\checkmark$ & & Jensen $2010 \mathrm{a}$ \\
\hline Oilseed rape [Brassica napus L.] & & $\checkmark$ & & Pekrun et al. 1998 \\
\hline Catchweed bedstraw (Galium aparine L.) & & $\checkmark$ & & Jensen 2009 \\
\hline $\begin{array}{l}\text { Ladysthumb [Persicaria lapathifolia (L.) } \\
\text { Delarbre.] }\end{array}$ & & $\checkmark$ & & Melander and Rasmussen 2000 \\
\hline Wild mustard (Sinapis arvensis L.) & & $\checkmark$ & & Melander and Rasmussen 2000 \\
\hline $\begin{array}{l}\text { Scentless chamomile [Tripleurospermum } \\
\text { perforatum (Merát) Laínz] }\end{array}$ & & $\checkmark$ & & $\begin{array}{l}\text { Jensen 2009; Melander and } \\
\text { Rasmussen } 2000\end{array}$ \\
\hline
\end{tabular}

problems. If not, this also suggests that cover crops should be established with minimum soil disturbance to enhance the loss of new seeds. Leaving the stubble untouched requires that perennials are not posing a problem or controlled by other means.

\section{Enhancement of Crop Growth}

Crop growth can be manipulated in various ways to augment its suppressive ability against weeds. Organic growers take advantage of methods that can increase crop performance to improve the outcome of weed control interventions (Melander et al. 2005). A gradual change of herbicide-based weed control towards IPM concepts will inevitably involve factors that can strengthen crop growth relative to weed growth. Fertilizer placement, crop variety choice, crop density and spatial arrangement, and crop sowing time are especially relevant in this context.

Placement of mineral fertilizer and injection/placement of slurry into the soil at the time of sowing of spring-sown cereals can improve crop competitiveness, effectiveness of mechanical and chemical weed control, and crop yield (Rasmussen 2002; Rasmussen et al. 1996). The crop gains an initial competitive advantage over weeds because the crop takes up nitrogen at higher rates than the weeds due to nutrients being placed closer to the crop seeds. Weed seeds capable of producing viable plants are more superficially placed in the soil and thus further away from the nutrients.

Christensen (1994) found considerable differences in the herbicide dose needed to attain a certain weed control level among different winter cereal crops and among different varieties within crops. For example, a $154 \%$ higher herbicide dose was needed in a winter wheat variety as compared to a winter barley variety to achieve the same effectiveness. Barley varieties can be indexed for their suppressive ability against weeds based on just four varietal growth traits: reflectance, leaf area index, leaf angle, and culm length (Hansen et al. 2008). The authors suggest indexation for competitiveness to become a standard practice in regular screening programs of cereal varieties. The suppressive ability of a cereal variety can be further improved by increasing crop density and spatial uniformity. Even a more randomized crop pattern can create a more competitive crop as compared to the common row pattern of cereals (Olsen et al. 2005).

Delaying sowing time of winter cereals can reduce weed pressure and improve crop growth relative to weed growth, whereby weed fecundity and weed impact on crop growth are reduced (Melander 1995; Rasmussen 2004). Delaying the sowing date of winter cereals, however, is always a balance between risking a yield penalty and savings in weed control inputs.

The interactive effects of these cultural tactics with RT have not been thoroughly studied under field conditions. The quantitative contribution in terms of savings in herbicide input would probably resemble what can be achieved in CT cropping systems. However, poor crop establishment, resulting in less competitive crop stands owing to RT might outweigh the positive effects aimed for with cultural methods. Problems with crop establishment can be caused by crop residues and poor seedbed quality impeding crop seed germination and early establishment (Melander et al. 2008; Morris et al. 2010; Peigné et al. 2007). Lack of suitable equipment also can constrain the employment of some cultural tactics, such as fertilizer placement and the establishment of uniform crop stands.

\section{Direct Nonchemical Control Methods}

Research into direct nonchemical methods in some European countries has benefitted from the political initiatives imposed to reduce pesticide dependence and promote a larger conversion to organic cropping (Melander et al. 2005). This trend has spread to even more European countries, although the granting of new projects in the development of new nonchemical technologies has not risen proportionally.

Direct control methods are regarded as those that can be used directly in a growing crop from the time of seed germination until crop harvest. Mechanical and thermal 
methods play a significant role in organic cropping, but have been mostly studied under CT regimes. Few methods have been taken up in conventional crop production, owing to insufficient feasibility. Lower efficacy, higher costs, and less ease of application as compared to herbicides are usually the major explanations brought forward (Melander et al. 2005). However, the continuous loss of herbicides in the EU, will surely increase conventional growers' awareness about the innovations made on nonchemical technologies for weed control.

Mechanical Control. The amount of crop residues and the workability of the soil generated by NIT will determine the possibilities for adopting direct mechanical interventions (Peigné et al. 2007). Obviously, mechanical weed control has no place in NT systems, but might have relevance in RT systems where some tillage precedes crop sowing. The loosening, uprooting, and burying mechanisms caused by cultivation can lethally affect weed plants, depending on timing and intensity of application (Kurstjens and Kropff 2001; Kurstjens and Perdok 2000; Terpstra and Kouwenhoven 1981).

Weed harrowing with flex-tine harrows in small grain cereals and pulse crops has been studied intensively under CT for the past $20 \mathrm{yr}$ (Melander et al. 2005; Rasmussen et al. 2010; Rueda-Ayala et al. 2011). It is an important control tactic for broadcast-sown crops in organic farming. Its weeding effectiveness is inversely related to weed growth stage at the time of treatment, and the avoidance of crop injuries relies on conditions for selective conduction and the operator's skills. The few attempts made to adopt the techniques to a NIT situation have clearly revealed major drawbacks, such as crop residues plugging the implement, soils difficult to till, high abundances of weed species being more tolerant to harrowing (notably grasses) and poor crop competition to suppress residual weeds after harrowing (Barberi et al. 2000; Johnson et al. 2007).

Rotary hoes are widely used in North America (Cloutier et al. 2007) and have potential as a useful weed management tool in NIT systems in Europe. The implement is gentler to the crop as compared to flex tine harrows, where settings can be more aggressive. However, rotary hoes are mainly effective against weeds at the white thread stage, with effectiveness declining rapidly as weeds develop. The time span in which weed control can be done is narrower than with flex tine harrows. Rotary hoes have currently very little use in European agriculture, but they appear to have more relevance for NIT systems than flex tine harrows. According to Johnson et al. (2007), rotary hoes can be modified to operate in the presence of crop residues and might become a useful tool to supplement reduced herbicide inputs in reduced-tillage systems.

Ground-driven and rotating weeding devices are also known to operate successfully in maize cropping. Especially gangs of wheels (e.g., "spiders" [curved teeth]), finger weeders mounted on interrow cultivators, and disk hillers can be used for both interrow and intrarow weed control; however, the results of the latter are strongly dependent on the conditions for selective application (Cloutier et al. 2007; van der Weide et al. 2008). These methods have mostly been studied with
CT in European research, and their applicability with residues remains unclear. To address this lack of knowledge, a multiyear experiment in maize was initiated in the Netherlands in 2009 comparing mechanical control to chemical control in several tillage systems (NT, ridge-tillage, striptillage, NIT, and CT) combined with five different green manure crops. Preliminary results have shown that mechanical weed control is practicable but at a higher risk in RT systems due to a higher weed pressure. The implements for mechanical control had to be modified to work in crop residues and more compacted soil (van der Weide et al. 2011).

Interrow cultivation is commonly employed in row crops in both conventional and organic farming (Melander et al. 2005). The technique has also been modified to work in conventional winter oil seed rape. Row spacing can be increased from the normal width of $12.5 \mathrm{~cm}$ to $50 \mathrm{~cm}$ without compromising yield, and modern interrow hoes can be automatically steered by cameras (Pedersen and Petersen 2011). The cultivators are mounted with goosefoot shares that effectively control interrow weeds with one or two passes in the autumn and sometimes another pass in early spring, depending on the weed pressure (Kristensen 1997). Intrarow weeds are less problematic than in cereals because the suppression inflicted by the crop is larger. Oil seed rape has a high growth rate from early spring onward, when leaves expand rapidly and stems elongate already from mid- to late April in normal years. The compensatory ability of oilseed rape, mainly achieved through branching, means that yield and weed suppression change little within a relatively large range of row spacing and crop plant densities (Lutman et al. 1993). Interrow cultivators have sufficient space between shanks to work in the presence of crop residues. The ability of stubble cultivators to incorporate crop residues has improved considerably, and NIT systems could therefore facilitate interrow weeding. However, this assumption still needs verification.

A new technology capable of precise placement of crop seeds is underway that has evolved from previous works on electronic crop seed mapping (e.g., Griepentrog et al. 2005). The technology uses GPS technology to create parallel or diamond crop establishment patterns, which enables interrow hoeing to be conducted in different directions, for example, $90^{\circ}$ offset to the seeding direction (Kverneland 2012). This could significantly improve mechanical control of intrarow weeds in both CT and NIT row-crop systems.

Thermal Control. Thermal methods such as flaming, steaming, hot water, UV-radiation, laser cutting, microwaves, and freezing are generally energy-demanding technologies. They have low work rates and relatively high purchase costs and might require multiple treatments for satisfactory control, and flaming can cause fires under certain circumstances (Ascard et al. 2007). So far, no thermal methods studied under CT have demonstrated any potential for use in major agricultural crops such as cereals, pulses, and oil seed rape. Ulloa et al. (2010) found that POST-broadcast flaming in winter wheat was too detrimental to the crop and only propane gas doses known to be ineffective against weeds could be tolerated. In maize, however, weed-effective propane gas doses can be used for broadcast flaming at the five-leaf growth 
stage with an acceptable impact on the crop (Ulloa et al. 2011). POST-broadcast flaming at early growth stages (oneto five-leaf stage) supplemented by interrow cultivation is currently applied on more than half the area grown with organic fodder maize in Denmark (The Knowledge Centre for Agriculture 2011). The results from maize are all from CT systems, and adopting flaming to maize RT systems would require another heat source to avoid fire hazards arising from kindled crop residues. Steam or hot foam might become relevant heat sources in this context, but in general, considerable innovation is needed to make broadcast thermal weed control feasible for large agricultural crops grown under RT.

\section{Concluding Remarks}

Reduced tillage crop production in Europe is heavily dependent on herbicide use, and will have to change fundamentally to comply with emerging legislation. The new standards for pesticide use set out by the European Commission and national pesticide action plans set the scene (Hillocks 2012). Reduced-tillage systems might fail if research, extension services, and manufacturers are not supporting agriculture with innovation and better guidance. Currently, RT systems in Europe rely largely on the access to glyphosate products. Success with RT systems without glyphosate and other herbicides will be extremely challenging and will require greater understanding of the interactions between weed dynamics and nonchemical weed management tactics.

The control of annual weeds in RT systems can be accomplished with fewer herbicides than are currently being used. An important prerequisite would be to evaluate the many crop sequences practiced today and redesign them to prevent the build-up of herbicide resistance and detrimental weeds, such as annual grass weeds and catchweed bedstraw. Certainly, EU subsidy programs promoting more varied crop sequences would greatly help. The ability of stubble cultivators to incorporate crop residues has been improved over the years, which can allow the use of interrow cultivation in winter oilseed rape and maize. This could limit herbicide input markedly, especially if interrow cultivation in maize is complemented by band spraying on the rows (Meissle et al. 2010). Whether full-width mechanical weed control methods in small grain cereals has any potential under RT remains to be seen. However, we do see some possibilities in rotating weeding devices, provided that they are further improved and modified to operate with crop residues and less workable soils.

Cover cropping and stubble management also might play a significant role for future crop protection programs, because the inclusion of these cropping techniques, if properly managed, can counteract the proliferation of weeds. Other cultural tactics aimed at strengthening crop growth and its suppressive ability against weeds also could contribute to limit the need for herbicides. We believe that there is considerable scope for adopting more nonchemical practices in today's noninversion tillage systems. The accumulated effect of applying multiple nonchemical tactics can reduce both treatment frequency and dosage of selective herbicides.

\section{Acknowledgments}

This review developed from a paper presented at the WSSA Annual Meeting at Waikoloa, Hawaii, February 2012. We thank Dan Brainard for inviting us to give the talk and for helpful discussions. Two anonymous referees are acknowledged for helpful comments on the manuscript.

\section{Literature Cited}

Altieri, M. A., M. A. Lana, H. V. Bittencourt, A. S. Kieling, J. J. Comin, and P. E. Lovato. 2011. Enhancing crop productivity via weed suppression in organic no-till cropping systems in Santa Catarina, Brazil. J. Sustain. Agric. 35:855869.

Andersson, T. N. and P. Milberg. 1996. Weed performance in crop rotations with and withoutt leys and at different nitrogen levels. Ann. Appl. Biol. 128:505-518.

Andersson, T. N. and P. Milberg. 1998. Weed flora and the relative importance of site, crop, crop rotation, and nitrogen. Weed Sci. 46:30-38.

Anonymous. 2012a. Bundesanstalt für Landwirtschaft und Ernährung. http:// www.nap-pflanzenschutz.de. Accessed: January 11, 2012.

Anonymous. 2012b. Ministère de L'Agriculture et de la Pechê. http://agriculture. gouv.fr/Ecophyto-in-English-1571. Accessed: March 12, 2012.

Ascard, J., P. E. Hatcher, B. Melander, and M. K. Upadhyaya. 2007. Chapter 10. Thermal weed control. Pages $155-175$ in M. K. Upadhyaya and R. E. Blackshaw, eds. Non-Chemical Weed Management: Principles, Concepts and Technology, Wallingford, UK: CAB International (www.cabi.org).

Barberi, P., N. Silvestri, A. Peruzzi, and M. Raffaelli. 2000. Finger harrowing of durum wheat under different tillage systems. Biol. Agric. Hortic. 17:285-303.

Blackshaw, R. E., R. L. Andersson, and D. Lemerle. 2007. Chapter 3. Cultural weed management. Pages 35-48 in M. K. Upadhyaya and R. E. Blackshaw, eds. Non-Chemical Weed Management: Principles, Concepts and Technology, Wallingford, UK: CAB International (www.cabi.org).

Bohan, D. A., S. J. Powers, G. Champion, A. J. Haughton, C. Hawes, G. Squires, J. Cussans, and S. K. Mertens. 2011. Modelling rotations: can crop sequences explain arable weed seedbank abundance? Weed Res. 51:422-432.

Cavan, G., J. Cussans, and S. R. Moss. 2000. Modelling different cultivation and herbicide strategies for their effect on herbicide resistance in Alopecurus myosuroides. Weed Res. 40:561-568.

Chauvel, B., C. Tschudy, and N. M. Munier-Jolain. 2011. Gestion intégrée de la flore adventice dans les systèmes de culture sans labour. Cah. Agric. 20:194203.

Chikowo, R., V. Faloya, S. Petit, and N. M. Munier-Jolain. 2009. Integrated weed management systems allow reduced reliance on herbicides and long-term weed control. Agric. Ecosyst. Environ. 132:237-242.

Christensen, S. 1994. Crop weed competition and herbicide performance in cereal species and varieties. Weed Res. 34:29-36.

Clarke, J., S. Moss, and J. Orson. 2000. The future for grass weed management in the U.K. Pesticide Outlook, April 2000, 11:59-63.

Cloutier, D. C., R. Y. van der Weide, A. Peruzzi, and M. L. Leblanc. 2007. Chapter 8. Mechanical weed management. Pages 111-134 in M. K. Upadhyaya and R. E. Blackshaw, eds. Non-Chemical Weed Management: Principles, Concepts and Technology, Wallingford, UK: CAB International (www.cabi.org).

Davies, D. B. and J. B. Finney. 2002. Reduced cultivation for cereals: research, development and advisory needs under changing economic circumstances. Home Grown Cereals Authority, Research Review. No. 48.57 p.

Dugon, J., G. Favre, A. Zimmermann, and R. Charles. 2010. Pratiques phytosanitaires dans un réseau d'exploitations de grandes cultures de 1992 à 2004. Rech. Agronomique Suisse 1:416-423.

ENDURE deliverable DR2.16. 2010. Designing Innovative Crop Protection Strategies in Arable Rotations: Winter Crops Based Cropping Systems. http:// www.endure-network.eu/endure_publications/deliverables. Accessed: December 15, 2011.

Erbach, D. C. and W. G. Lovely. 1975. Effect of plant residue on herbicide performance in no-tillage corn. Weed Sci. 23:512-515.

EU Directive/128/EC. 2009. Directive/128/EC of The European Parliament and of The Council. Official Journal of The European Union L309:71-86.

Ferguson, A. and N. Evans. 2010. Reducing Pesticide Inputs in Winter Cropping Systems in the UK. Winter Crops Based Cropping Systems (WCCS). Case 
Study-Guide Number 3. http://www.endure-network.eu/ endure_publications/endure_publications2. Accessed: December 15, 2011.

Fortino, G., L. Guichard, E. Lô-Pelzer, R. Reau, M. Valantin-Morison, and X. Pinochet. 2010. Redesigning Cropping Systems in Three French Regions. Winter Crops Based Cropping Systems (WCCS). Case Study-Guide Number 2. http://www.endure-network.eu/endure_publications/ endure_publications2. Accessed: December 15, 2011.

Freier, B., J. Sellmann, J. Scwarz, M. Jahn, E. Moll, V. Gutsche, and W. Zornbach. 2010. Netz Vergleichsbetriebe Pflanzenschutz Jahresbericht 2010. Berichte aus dem Julius Kühn-Institut 161, pp. 83. http://pub.jki.bund.de/ index.php/BerichteJKI/article/viewFile/1676/2017. Accessed: April 3, 2012.

Froud-Williams, R. J., D.S.H. Drennan, and R. J. Chancellor. 1983. Influence of cultivation regime on weed floras of arable cropping systems. J. Appl. Ecol. 20:187-197.

Griepentrog, H., M. Nørremark, H. Nielsen, and B. Blackmore. 2005. Seed mapping of sugar beet. Precis. Agric. 6:157-165.

Gruber, S. and W. Claupein. 2009. Effect of tillage intensity on weed infestation in organic farming. Soil Tillage Res. 105:104-111.

Hansen, P. K., K. Kristensen, and J. Willas. 2008. A weed suppressive index for spring barley (Hordeum vulgare) varieties. Weed Res. 48:225-236.

Hanzlik, K. and B. Gerowitt. 2011. The importance of climate, site and management on weed vegetation in oilseed rape in Germany. Agric. Ecosyst. Environ. 141:323-331.

Hillocks, R. J. 2012. Farming with fewer pesticides: EU pesticide review and resulting challenges for UK agriculture. Crop Prot. 31:85-93.

Holland, J. M. 2004. The environmental consequences of adopting conservation tillage in Europe: reviewing the evidence. Agric. Ecosyst. Environ. 103:1-25.

Jacobsen, B. H. and J. E. Ørum. 2009. Farm economic and environmental effects of reduced tillage. Food Economics-Acta Agric. Scand. C-E 6:134-142.

Jensen, P. K. 2009. Longevity of seeds of four annual grasses and two dicotyledon weed species as related to placement in the soil and straw disposal technique. Weed Res. 49:592-601.

Jensen, P. K. 2010a. Longevity of seeds of Poa trivialis and Vulpia myuros as affected by simulated soil tillage practices and straw disposal technique. Grass Forage Sci. 65:76-84.

Jensen, P. K. 2010b. Longevity of seeds of Poa pratensis and Lolium perenne as affected by simulated soil tillage practices and its implications for contamination of herbage seed crops. Grass Forage Sci. 65:85-91.

Johnson, E. N., A. G. Thomas, J. Y. Leeson, S. J. Shirtliffe, and S. A. Brandt. 2007. Mechanical weed control in pulse and cereal crops: is there a fit in largescale western Canadian agriculture?. Pages 45-58 in D. C. Cloutier and M. L. Leblanc, eds. Topics in Canadian Weed Science. Physical Weed Control: Progress and Challenges. Vol. 6. Pinawa, Manitoba, Canada: Canadian Weed Science Society.

Jørgensen, L. N. and P. Kudsk. 2006. Twenty years' experience with reduced agrochemical inputs. Pages 16.1-16.10 in Proceedings of the Home Grown Cereal Authority, Research \& Development Conference. Arable Crop Protection in the Balance Profit and the Environment, January 25-26, 2006, Lincolnshire, UK. Kenilworth, UK: HGCA Agriculture and Horticulture Development Board.

Kristensen, H. 1997. Erfaringer med mekanisk ukrudtsbekæmpelse i raps. Pages 179-182 in Proceedings of the 14th Danish Plant Protection Conference/ Weeds. Nyborg, Denmark: Danish Institute of Agricultural Sciences.

Kurstjens, D.A.G. and M. J. Kropff. 2001. The impact of uprooting and soilcovering on the effectiveness of weed harrowing. Weed Res. 41:211-228.

Kurstjens, D.A.G. and U. D. Perdok. 2000. The selective soil covering mechanism of weed harrows on sandy soil. Soil Tillage Res. 55:193-206.

Kverneland. 2012. Electric Drive GEOseed Offers New Opportunities. http://dk. kverneland.com/Nyheder/Kverneland-Nyheder/Electric-drive-GEOseedoffers-new-opportunities. Accessed: January 25, 2012.

Labreuche, J., J. Roger-Estrade, I. Feix, T. Viloingt, D. Caboulet, J. P. Daouze, R. Duval, A. Ganteil, L. Quéré, H. Boizard, L. Jouy, and G. Thevenet. 2008. Les techniques culturales sans labour concernent un tiers des surfaces françaises. Perspect. Agricoles 342:38-43.

Ledermann, T., K. Herweg, H. P. Liniger, F. Schneider, H. Hurni, and V. Prasuhn. 2010. Applying erosion damage mapping to assess and quantify offsite effects of soil erosion in Switzerland. Land Degrad. Dev. 21:353-366.

Lu, Y. C., K. B. Watkins, J. R. Teasdale, and A. A. Abdul-Baki. 2000. Cover crops in sustainable food production. Food Rev. Int. 16:121-157.

Lukashyk, P., M. Berg, and U. Köpke. 2008. Strategies to control Canada thistle (Cirsium arvense) under organic farming conditions. Renew. Agric. Food Syst. 23:13-18.
Lutman, P.J.W., P. Bowerman, G. M. Palmer, and G. P. Whytock. 1993. The competitive effects of broad-leaved weeds in winter oilseed rape. Pages 10231028 in Proceedings of the 1993 Brighton Crop Protection Conference (Weeds). Brighton, UK: British Crop Protection Council.

Mamarot, J. 2005. Gérer les mauvaises en non-labour. Des références obtenues en Midi-Pyrénées. Phytoma, La Défense des Végétaux 582:60-64.

Meissle, M., P. Mouron, T. Musa, F. Bigler, X. Pons, V. P. Vasileiadis, S. Otto, D. Antichi, J. Kiss, Z. Pálinkás, Z. Dorner, R. Van der Weide, J. Groten, E. Czembor, J. Adamczyk, J. B. Thibord, B. Melander, G. C. Nielsen, R. T. Poulsen, O. Zimmermann, A. Verschwele, and E. Oldenburg. 2010. Pests, pesticide use and alternative options in European maize production: current status and future prospects. J. Appl. Entomol. 134:357-375.

Melander, B. 1994. Impact of non-inversion tillage on weeds in temperate regions. Pages 49-58 in F. Tebrügge and A. Böhrnsen eds. Workshop I of EU Concerted Action 27-28 June: Experiences with the Applicability of NoTillage Crop Production in the West-European Countries. Giessen, Germany. Langgöns, Germany: Wissenschaftlicher Fachverlag.

Melander, B. 1995. Impact of drilling date on Apera spica-venti L. and Alopecurus myosuroides Huds. in winter cereals. Weed Res. 35:157-166.

Melander, B. 1998. A review of the major experiences with weeds in noninversion tillage systems within the European Economic Community (EEC. Pages 63-68 in F. Tebrügge and A. Böhrnsen eds. Final Report of EU Concerted Action: Experiences with the Applicability of No-Tillage Crop Production in the West-European Countries. Giessen, Germany: Fachverlag Köhler,

Melander, B., N. Holst, P. K. Jensen, E. M. Hansen, and J. E. Olesen. 2008. Apera spica-venti population dynamics and impact on crop yield as affected by tillage, crop rotation, location and herbicide programmes. Weed Res. 48:4857.

Melander, B., L. N. Jørgensen, and R. T. Poulsen. 2010a. IPM in Danish Winter Crops Based Cropping Systems. Winter Crops Based Cropping Systems (WCCS). Case Study_Guide Number 1. http://www.endure-network.eu/ endure_publications/endure_publications2. Accessed: December 15, 2011.

Melander, B., P. Kudsk, S. Mathiassen, L. N. Jørgensen and L. M. Hansen. 2010b. Planteværnsproblemer i forbindelse med reduceret jordbearbejdning. Intern Rapport, Markbrug nr. 29, September 2010. Aarhus Universitet. Denmark: Aarhus University 27 p.

Melander, B. and K. Rasmussen. 2000. Reducing intrarow weed numbers in row crops by means of a biennial cultivation system. Weed Res. 40:205-218.

Melander, B., I. A. Rasmussen, and P. Barberi. 2005. Integrating physical and cultural methods of weed control-examples from European research. Weed Sci. 53:369-381

Mirsky, S. B., W. S. Curran, D. M. Mortensen, M. R. Ryan, and D. L. Shumway. 2011. Timing of cover-crop management effects on weed suppression in no-till planted soybean using a roller-crimper. Weed Sci. 59:380-389.

Moonen, A. C. and P. Bàrberi. 2004. Size and composition of the weed seedbank after 7 years of different cover crop-maize management systems. Weed Res. 44:163-177

Morris, N. L., P.C.H. Miller, J. H. Orson, and R. J. Froud-Williams. 2010. The adoption of non-inversion tillage systems in the United Kingdom and the agronomic impact on soil, crops, and the environment-a review. Soil Tillage Res. 108:1-15.

Neve, P., A. Diggle, F. P. Smith, and S. B. Powles. 2003. Simulating evolution of glyphosate resistance in Lolium rigidum II: past, present and future glyphosate use in Australian cropping. Weed Res. 43:418-427.

Olesen, J. E., E. M. Hansen, M. Askegaard, and I. A. Rasmussen. 2007. The value of catch crops and organic manures for spring barley in organic arable farming. Field Crops Res. 100:168-178.

Olsen, J., L. Kristensen, J. Weiner, and H. W. Griepentrog. 2005. Increased density and spatial uniformity increase weed suppression by spring wheat. Weed Res. 45:316-321.

Orson, J. H. 2006. Weed and pest management. Pages 46-53 in Tillage Systems for the Benefit of Agriculture and the Environment. "Extended abstracts." NJF Seminar 378, Odense, Denmark. Nordic Association of Agricultural Scientists. http://www.njf.nu/seminars/378/. Accessed: December 23, 2011.

Pallutt, B. 2010. 30 Jahre Feldversuche zum Pflanzenschutz. J. für Kulturpflanzen 62: 230-237.

Pallutt, B. 2011. Pflügen oder Nichtpflügen-Konsequenzen für den Pflanzenschutz. LandInForm Spezial 2:45-46.

Pedersen, H. J., P. Kudsk, and A. Helweg. 1995 Adsorption and ED50 values of five soil applied herbicides. Pestic. Sci. 44:131-136. 
Pedersen, J. and P. H. Petersen. 2011. Radrensning af majs og raps. Farmtest Maskiner og Planteavl 118. Aarhus, Denmark: Videnscentret for Landbrug. $33 \mathrm{p}$.

Peigné, J., B. C. Ball, J. Roger-Estrade, and C. David. 2007. Is conservation tillage suitable for organic farming? A review. Soil Use Manag. 23:129-144.

Pekrun, C. and W. Claupein. 2004. The effect of stubble tillage and primary tillage on population dynamics of Canada thistle (Cirsium arvense) in organic farming. J. Plant Dis. Prot., Special Issue XIX:483-490.

Pekrun, C. and W. Claupein. 2006. The implication of stubble tillage for weed population dynamics in organic farming. Weed Res. 46:414-423.

Pekrun, C., J.D.J. Hewitt, and P.J.W. Lutman. 1998. Cultural control of volunteer oilseed rape (Brassica napus). J. Agric. Sci. 130:155-163.

Rasmussen, I. A. 2004. The effect of sowing date, stale seedbed, row width and mechanical weed control on weeds and yields of organic winter wheat. Weed Res. 44:12-20.

Rasmussen, J., H. Mathiasen, and B. M. Bibby. 2010. Timing of post-emergence weed harrowing. Weed Res. 50:436-446.

Rasmussen, K. 2002. Influence of liquid manure application method on weed control in spring cereals. Weed Res. 42:287-298.

Rasmussen, K., J. Rasmussen, and J. Petersen. 1996. Effects of fertiliser placement on weeds in weed harrowed spring barley. Acta Agric. Scand. Sect. B Soil Plant Sci. 3:192-196.

Rasmussen, K. J. 1984. Methods of tillage for spring barley on coarse sandy soils. Dan. J. Plant Soil Sci. 88:443-452.

Rueda-Ayala, V. P., J. Rasmussen, R. Gerhards, and N. E. Fournaise. 2011. The influence of post-emergence weed harrowing on selectivity, crop recovery and crop yield in different growth stages of winter wheat. Weed Res. 51:478-488.

Schwarz, J. and E. Moll. 2010. Entwicklung der Verunkrautung in Abhängigkeit von Fruchtfolge und Herbizidintensität. Journal für Kulturpflanzen 62: 317325

Soane, B. D., B. C. Ball, J. Arvidsson, G. Basch, F. Moreno, and J. RogerEstrade. 2012. No-till in northern, western and south-western Europe: a review of problems and opportunities for crop production and the environment. Soil Tillage Res. 118:66-87.

Teasdale, J. R. 1996. Contribution of cover crops to weed management in sustainable agricultural systems. J. Prod. Agric. 9:475-479.

Terpstra, R. and J. K. Kouwenhoven. 1981. Inter-row and intra-row weed control with a hoe ridger. J. Agric. Eng. Res. 26:127-134.

The Knowledge Centre for Agriculture. 2011. http://www.landbrugsinfo.dk/ Oekologi. Accessed: December 18, 2011.
Thorup-Kristensen, K., J. Magid, and L. S. Jensen. 2003. Catch crops and green manures as biological tools in nitrogen management in temperate zones. Adv. Agron. 79:227-302.

Ulloa, S. M., A. Datta, C. Bruening, B. Neilson, J. Miller, G. Gogos, and S. Z. Knezevic. 2011. Maize response to broadcast flaming at different growth stages: effects on growth, yield and yield components. Eur. J. Agron. 34:1019 .

Ulloa, S. M., A. Datta, and S. Z. Knezevic. 2010. Growth stage impacts tolerance of winter wheat (Triticum aestivum L.) to broadcast flaming. Crop Prot. 29:1130-1135.

van der Weide, R. Y., P. O. Bleeker, V.T.J.M. Achten, L.A.P. Lotz, F. Fogelberg, and B. Melander. 2008. Innovation in mechanical weed control in crop rows. Weed Res. 48:215-224.

van der Weide, R. Y., H. F. Huiting, P. O. Bleeker, and M. M. Riemens. 2011. Pro's and con's of reduced tillage in maize with respect to weeds. Pages 13-14 in Proceedings of the 9th EWRS Workshop on Physical and Cultural Weed Control, Samsun, Turkey. The European Weed Research Society. http://www. ewrs.org/pwc/proceedings.asp. Accessed: September 18, 2012.

Vasileiadis, V. P., M. Sattin, S. Otto, A. Veres, Z. Pálinkás, X. Pons, P. Kudsk, R. van der Weide, E. Czembor, C. Moonen, and J. Kiss. 2011. Crop protection in European maize-based cropping systems: current practices and recommendations for innovative Integrated Pest Management. Agric. Syst. 104:533-540.

Vullioud, P., N. Delabays, P. Frei, and E. Mercier. 2006. Résultats de 35 ans de culture sans labour à Changins III. Mauvaises herbes, maladies fongiques et ravageurs. Rev. Suisse Agric. 38:81-87.

Vullioud, P. and E. Mercier. 2004. Résultats de 34 ans de culture sans labour à Changins. I. Evolution des rendements. Rev. Suisse Agric. 36:202-212.

Wilson, B. J. and K. J. Wright. 1991. Effects of cultivation and seed shedding on the population dynamics of Galium aparine in winter wheat crops. Pages 813820 in Proceedings of the Brighton Crop Protection Conference, Weeds. Vol. 2. Farnham, UK: British Crop Protection Council.

Zwerger, P., K. Hurle, and A. Kemmer. 1990. Untersuchungen zum Einfluss von Fruchtfolge und Anbauintensität auf die Entwicklung des Unkrautsamengehaltes im Boden. Pages 127-133 in Proceedings of the European Weed Research Society Symposium, Helsinki, Finland. Vammala, Finland European Weed Research Society.

Received April 17, 2011, and approved August 30, 2012. 